\title{
Techno-economic evaluation of oxy-combustion coal-fired power plants
}

\author{
XIONG Jie, ZHAO HaiBo* \& ZHENG ChuGuang \\ State Key Laboratory of Coal Combustion, Huazhong University of Science and Technology, Wuhan 430074, China
}

Received December 14, 2010; accepted July 28, 2011

\begin{abstract}
Increasing attention is being paid to the oxy-combustion technique of coal-fired power plants because $\mathrm{CO}_{2}$ produced from fossil fuel combustion can be captured and sequestrated by it. However, there are many questions about the economic properties of the oxy-combustion technique. In this paper, a detailed techno-economic evaluation study was performed on three typical power plants $(2 \times 300 \mathrm{MW}$ subcritical, $2 \times 600 \mathrm{MW}$ supercritical, $2 \times 1000 \mathrm{MW}$ ultra supercritical), as conventional air fired and oxycombustion options in China, by utilizing the authoritative data published in 2010 for the design of coal-fired power plants. Techno-economic evaluation models were set up and costs of electricity generation, $\mathrm{CO}_{2}$ avoidance costs as well as $\mathrm{CO}_{2}$ capture costs, were calculated. Moreover, the effects of $\mathrm{CO}_{2}$ tax and $\mathrm{CO}_{2}$ sale price on the economic characteristics of oxy-combustion power plants were also considered. Finally, a sensitivity analysis for parameters such as coal sample, coal price, air separation unit price, flue gas treatment unit price, $\mathrm{CO}_{2}$ capture efficiency, as well as the air excess factor was conducted. The results revealed that: (1) because the oxy-combustion technique has advantages in thermal efficiency, desulfurization efficiency and denitration efficiency, oxy-combustion power plants will reach the economic properties of conventional air fired power plants if, (a) the $\mathrm{CO}_{2}$ emission is taxed and the high purity $\mathrm{CO}_{2}$ product can be sold, or (b) there are some policy preferences in financing and coal price for oxy-combustion power plants, or (c) the power consumption and cost of air separation units and flue gas treatment units can be reduced; (2) from subcritical plants to supercritical and finally ultra-supercritical plants, the economics are improving, regardless of whether they are conventional air fired power plants or oxy-combustion power plants.
\end{abstract}

oxy-combustion, $\mathrm{CO}_{2}$ emission control, techno-economics, sensitivity analysis, $\mathrm{CO}_{2}$ tax, $\mathrm{CO}_{2}$ sale, cost of electricity

Citation: $\quad$ Xiong J, Zhao H B, Zheng C G. Techno-economic evaluation of oxy-combustion coal-fired power plants. Chinese Sci Bull, 2011, 56: 3333-3345, doi: 10.1007/s11434-011-4707-5

As a branch of practical economics, techno-economics is widely used to research the economic benefits of technology application activities, achieve the best combination of technology and economy, seek ways to enhance economy benefit, and provide a decision basis for investment decision makers. Because coal-fired power plants are technologyintensive and capital-intensive processes, a techno-economic evaluation is particularly important. Many techno-economic evaluation studies have been conducted on the desulfurization $\left(\mathrm{De}-\mathrm{SO}_{x}\right)$ and denitration $\left(\mathrm{De}-\mathrm{NO}_{x}\right.$ ) processes in conventional coal-fired power plants. $\mathrm{CO}_{2}$ emission control has become a global issue [1], and actions to minimize emis-

*Corresponding author (email: klinsmannzhb@163.com) sions are a priority [2]. At present, $\mathrm{CO}_{2}$ capture and sequestration from power plants is a feasible and effective choice. And as $\mathrm{CO}_{2}$ emission control technologies, such as oxycombustion technology, integrated gasification combined cycle (IGCC) technology, monoethanolamine (MEA) and MEA/MDEA (activated methyldiethanolamine) scrubbing technology, have reached the commercialization phase, greater attention has been paid to the economic costs of these new technologies. Techno-economic analysis of the emission control technologies is one of the key problems that must be solved. Oxy-combustion is a new technology that adds a cryogenic air separation process (ASU) and a flue gas clean and purification process (CPU) to a conventional combustion process. High purity oxygen product 
from the ASU, instead of air, is used in the oxy-combustion process, and about $70 \%-80 \%$ of the flue gas is recycled into the furnace, keeping the combustion temperature inside the furnace within the conventional range. A schematic diagram of the oxy-combustion technology is shown in Figure 1. Because there is no nitrogen dilution, the $\mathrm{CO}_{2}$ concentration in the oxy-combustion flue gas is high, and a high purity $\mathrm{CO}_{2}$ product $(95 \%-99 \%)$ can be obtained through purification, compression and separation. Moreover, efficient De$\mathrm{SO}_{x}$ and De- $\mathrm{NO}_{x}$ can be achieved in such a system and consequently oxy-combustion has become one of the most competitive coal combustion technologies of this century. At present, oxy-combustion technology has reached the demonstration stage in many countries, and there were eight demonstration power station projects operating worldwide in 2008-2010. In this paper, techno-economic evaluations of oxy-combustion and also conventional coal-fired power plants are performed. The results of these two evaluations are compared and presented. In conventional coal-fired power plants, coal is combusted with air in the furnace and the flue gas containing about $15 \mathrm{~mol} \% \mathrm{CO}_{2}$ is emitted directly into the atmosphere.

IHI in Japan [3], Chalmers University of Technology in Sweden [4], ALSTOM in America [5], Argonne National Laboratory in America [6], CANMET in Canada [7] and EDF in France [8] have all carried out techno-economic evaluations of the oxy-combustion technology. The results of IHI [3] show that the efficiency of the oxy-combustion power plant (1000 MW) decreases $10.5 \%$; the results from Chalmers University of Technology [4] show that the efficiency of the oxy- combustion power plant (865 MW) decreases $9.1 \%$, the $\mathrm{CO}_{2}$ avoidance cost is $\$ 26 / \mathrm{t}$ and the cost of electricity is $\$ 64.3 / \mathrm{kW}$; the results of ALSTOM [5] show that the $\mathrm{CO}_{2}$ avoidance cost of the oxy-combustion power plant $(450$ $\mathrm{MW}$ ) is $\$ 42 / \mathrm{t}$ and the unit investment cost is $\$ 823 / \mathrm{kW}$; the results of Argonne National Laboratory [6] show that the $\mathrm{CO}_{2}$ avoidance cost is $\$ 34 / \mathrm{t}$; the results of CANMET [7] show that the $\mathrm{CO}_{2}$ avoidance cost of the oxy-combustion power plant (400 MW) is $\$ 35 / \mathrm{t}$, the cost of electricity increases $20 \%-30 \%$ and the unit investment cost is $\$ 791 / \mathrm{kW}$; the results of EDF [8] show that the efficiency of the oxycombustion power plant (1200 MW) decreases $10 \%$, the investment cost increases $69 \%$, the cost of electricity increases $48 \%$ and the $\mathrm{CO}_{2}$ avoidance cost of the oxy-combustion system is $29 \%$ lower than that of the MEA scrubbing system. These results can be summarized as: if conventional coal-fired power plants are retrofitted to be oxy-combustion power plants, the net power output will decrease by about $25 \%$, the cost of electricity will increase by $30 \%-50 \%$, the $\mathrm{CO}_{2}$ avoidance cost is about $\$ 30 / \mathrm{t}$ and about $85 \% \mathrm{CO}_{2}$ can be captured. However, the techno-economic characteristics of $\mathrm{CO}_{2}$ emission control systems are complicated. They depend on the energy efficiency of the system, technology maturity level, pollutants (including $\mathrm{SO}_{x}, \mathrm{NO}_{x}, \mathrm{PM} 10$ and $\mathrm{CO}_{2}$ ) emission policies in the country or the local region, and even financial policies (such as the loan interest rate and inflation rate). Since there are large differences among the evaluating system sizes and combustion conditions from various academic institutions, and the tax policies and financial policies between Western countries are usually adopted from country-specific data, the published research results are not transferable to the Chinese situation. Therefore, to provide the basis of policy decisions, it is very important to perform techno-economic evaluations for different $\mathrm{CO}_{2}$ emission control systems based on Chinese conditions and data, for energy and power systems, by comparing various electricity costs, $\mathrm{CO}_{2}$ avoidance costs and $\mathrm{CO}_{2}$ capture costs for these $\mathrm{CO}_{2}$ emission control systems.

The authors have previously performed a techno-economic evaluation of oxy-combustion coal-fired power plants retrofitted from conventional coal-fired power plants, by using a thermo-economic cost model [9] and practical investigation data [10]. However, some internal cost items (such as depreciation cost, amortization expense, material

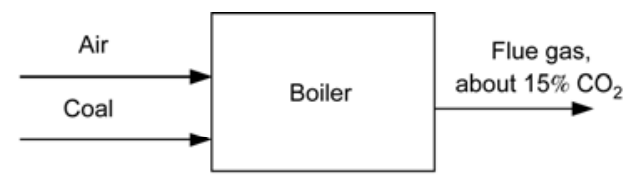

(a)

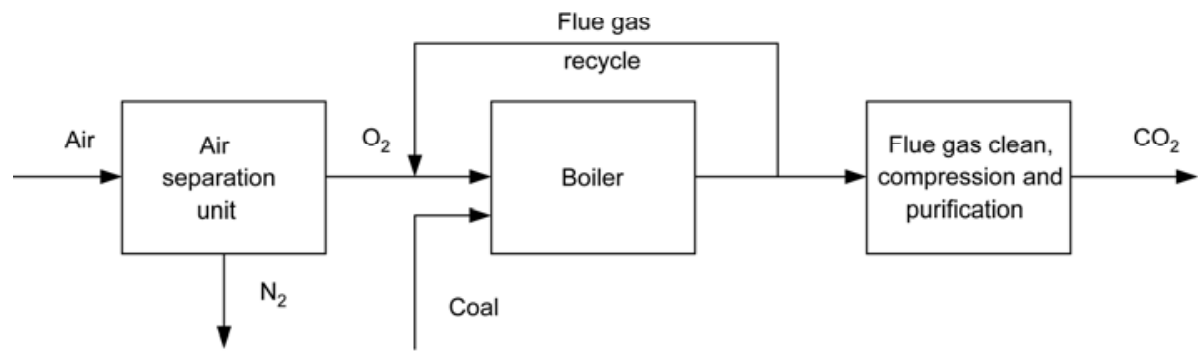

(b)

Figure 1 Schematic diagrams of the oxy-combustion technology and the conventional combustion technology. (a) Conventional combustion; (b) Oxy-combustion. 
cost, personnel wages and other expenses) were ignored in the previous models. Cost models for De-SO $\mathrm{SO}_{x}$ and De-NO technologies were very simple, and also detailed comparisons among several typical coal-fired power plants were not carried out. In this paper, a more systematic and comprehensive techno-economic evaluation of the oxy-combustion technology was thus conducted. Each factor during the electricity cost formation and detailed investment and operating costs of De-SO $\mathrm{S}_{x}$ and De-NO $\mathrm{NO}_{x}$ devices, was considered. Moreover, three typical coal-fired power plants $(2 \times 300$ MW subcritical, $2 \times 600$ MW supercritical and $2 \times 1000$ MW ultra-supercritical) in China were chosen to calculate the electricity costs in oxy-combustion power plants and conventional power plants, and $\mathrm{CO}_{2}$ avoidance costs and $\mathrm{CO}_{2}$ capture costs in oxy-combustion power plants. The effects of a $\mathrm{CO}_{2}$ tax, and $\mathrm{CO}_{2}$ sale price, on the cost results are also discussed. Finally, a sensitivity analysis of some important parameters in oxy-combustion systems, such as the coal price, ASU cost, $\mathrm{CPU}$ cost and $\mathrm{CO}_{2}$ capture efficiency, were performed to study their influences on the economics of the oxy-combustion technology.

\section{Techno-economic analysis}

\subsection{Basic methods}

Because there are no demonstration or commercially operated oxy-combustion coal-fired power plants larger than $30 \mathrm{MW}$, the techno-economic evaluation of an oxy-combustion plant was performed based on its corresponding conventional coal-fired power plant. Keeping the gross power outputs of the oxy-combustion plant and its corresponding conventional plant equivalent, the differences in the oxy-combustion plant from the conventional plant mainly lie in: retrofitting the burner, heat exchange surface and flue gas recycle in the boiler island; an ASU and a CPU are added. Consequently, the techno-economic evaluation process of an oxy-combustion plant is as follows:

(1) Collect basic thermodynamic parameters (such as coal consumption rate, power generation load, and boiler efficiency), operational conditions (such as annual operation hours, maintenance factor, amortization rate, depreciation rate, and personnel wages), and investment and operational costs of $\mathrm{De}-\mathrm{SO}_{x}$ and De- $\mathrm{NO}_{x}$ devices, in the conventional plant system, that can be obtained from a system process simulation, or investigation. In this paper, data were adopted mainly from the book "Reference cost indexes in quota design for coal-fired projects (2009 levels)" [11] published by the China Power Engineering Consulting Group Corporation in 2010. The boiler retrofit cost, investment cost and power consumption of CPU could be estimated and adjusted by referring to published papers $[12,13]$. The investment cost and power consumption of ASU can be obtained from oxygen production companies and by simulating the ASU system.

(2) Generally, commercial loans exist for the construc- tion of a power plant, so it is necessary to know the market economy policies, such as interest rate, fuel price, water price, steam price, limestone price and gypsum price.

(3) From the data mentioned above, each basic cost item (such as fuel cost and investment cost) relating to the oxycombustion and conventional plants can be calculated. Then the $\mathrm{CO}_{2}$ avoidance costs and $\mathrm{CO}_{2}$ capture costs of the oxycombustion plants can be further calculated. Finally, a sensitivity analysis may be performed.

\subsection{Cost calculation for power plants}

The total cost of a power plant includes the power generation cost, period cost, and by-products revenue $\left(C_{10}\right)$. The power generation cost includes fuel cost $\left(C_{1}\right)$, operation and maintenance $(\mathrm{O} \& \mathrm{M})$ cost $\left(C_{3}\right)$, depreciation cost $\left(C_{4}\right)$, amortization cost $\left(C_{5}\right)$, pollutants' emission tax $\left(C_{6}\right)$, personnel wages $\left(C_{7}\right)$, material cost $\left(C_{8}\right)$ and other costs $\left(C_{9}\right)$. The period cost includes a management expense and financial expense (including loan interest $\left(C_{2}\right)$ ). Because the management expense and financial expense involve complicated financial accounting theory and industry rules, only some "hard" costs (annualized cost $C_{\mathrm{T}}$ ) were considered in this paper, which can be described as

$$
C_{\mathrm{T}}=\sum_{i=1}^{9} C_{i}-C_{10}
$$

(i) Cost calculation for conventional power plants. Conventional power plant costs can be calculated as follows:

(1) Fuel cost

$$
C_{1,0}=m_{\mathrm{F}, 0} \times c_{\mathrm{F}} \times W \times H,
$$

in which, $m_{\mathrm{F}, 0}$ is the unit standard coal consumption rate for power generation $(315,299$ and $275 \mathrm{~g} /(\mathrm{kW} \mathrm{h})$ for the subcritical, supercritical and ultra-supercritical power plant, respectively in this paper) [11], $c_{\mathrm{F}}$ is the unit standard coal price (680 ¥/t with tax [11], ¥ is the symbol of Chinese Yuan (CNY). $1 \mathrm{US} \$=6.8 \mathrm{CNY}$ in 2009), $W$ is the power plant load (600, 1200 and $2000 \mathrm{MW}$ for the three kinds of power plant) and $H$ is the annual operation hours (5000 h [11]). The ultimate analysis and the lower heating value $\left(H_{\mathrm{i}}\right)$ of the raw coal (Shenhua coal) are listed in Table 1. The unit oxygen needed $\left(v_{\mathrm{O}}\right)$ for combustion can be calculated to be $1.27 \mathrm{Nm}^{3} / \mathrm{kg}$ coal on the basis of values in Table 1 and eq. (3).

$$
v_{\mathrm{O}}=\left(\mathrm{C}_{\mathrm{ar}} / 12+\mathrm{H}_{\mathrm{ar}} / 4+\mathrm{S}_{\mathrm{ar}} / 32-\mathrm{O}_{\mathrm{ar}} / 32\right) \times 22.4 .
$$

(2) Loan interest cost

$$
C_{2,0}=C_{\mathrm{IT}, 0} \times p_{\text {loan }} \times \xi,
$$

in which, $C_{\mathrm{IT}, 0}$ is the total investment cost of the conventional power plant and $C_{\mathrm{IT}, 0}=C_{\mathrm{IT}, \mathrm{base}, 0}+C_{\mathrm{IT}, \mathrm{S}, 0}+C_{\mathrm{IT}, \mathrm{N}, 0}$. The $C_{\text {IT,base }, 0}$ for the three kinds of power plant (excluding De-SO $\mathrm{SO}_{x}$ 
Table 1 Ultimate analysis and lower heating value of the Shenhua coal

\begin{tabular}{cccccccc}
\hline $\mathrm{M}_{\mathrm{ar}}(\%)$ & $\mathrm{A}_{\mathrm{ar}}(\%)$ & $\mathrm{C}_{\mathrm{ar}}(\%)$ & $\mathrm{H}_{\mathrm{ar}}(\%)$ & $\mathrm{O}_{\mathrm{ar}}(\%)$ & $\mathrm{N}_{\mathrm{ar}}(\%)$ & $\mathrm{S}_{\mathrm{ar}}(\%)$ & $H_{\mathrm{i}}(\mathrm{kJ} / \mathrm{kg})$ \\
\hline 13.8 & 11 & 60.51 & 3.62 & 9.94 & 0.7 & 0.43 & 22768 \\
\hline
\end{tabular}

and De- $\mathrm{NO}_{x}$ devices) can be estimated by using 4412,3675 and $3591 ¥ / \mathrm{kW}$ [11]. The device costs of the $\mathrm{De}^{-\mathrm{SO}_{x}}$ devices (considering the wet flue gas desulfurization (FGD) technology with a $95 \%$ desulfurization efficiency $\left.\left(\eta_{\mathrm{S}, 0}\right)\right)$ in the three plants are 111.43, 185.45, 247.09 M¥, respectively [11]. The device costs of the denitration devices (considering the selective catalytic reduction (SCR) denitration technology with a $80 \%$ denitration efficiency $\left.\left(\eta_{\mathrm{N}, 0}\right)\right)$ in the three plants are 72.99, 108 and $140 \mathrm{M} ¥$, respectively [11]. In addition, the costs of De-SO $\mathrm{S}_{x}$ and De- $\mathrm{NO}_{x}$ devices are set to be $80 \%$ of their investment costs $\left(C_{\mathrm{IT}, \mathrm{S}, 0}\right.$ and $\left.C_{\mathrm{IT}, \mathrm{N}, 0}\right)[14,15]$ and other costs, such as construction, installation and technical service, account for the remaining $20 \%$; $p_{\text {loan }}$ is the loan percentage (80\% [11]), and the "average capital method" was chosen to payback the load, the average interest rate can be calculated by $\xi=i \times(1+1 / P) / 2, P$ is the loan period $(15,18$ and 18 years, respectively [11]), $i$ is the loan interest rate for a period longer than 5 years $(5.94 \%$ [11]).

(3) Operation and maintenance cost

$$
C_{3,0}=C_{\mathrm{IT}, \text { base }, 0} \times p_{\mathrm{OM}, \text { base }, 0}+C_{\mathrm{OM}, \mathrm{S}, 0}+C_{\mathrm{OM}, \mathrm{N}, 0},
$$

in which, $p_{\text {OM,base, } 0}$ is the O\&M coefficient (2.5\% [7], including the major maintenance expense) for the conventional power plants (excluding $\mathrm{De}-\mathrm{SO}_{x}$ and $\mathrm{De}-\mathrm{NO}_{x}$ devices); $C_{\mathrm{OM}, \mathrm{S}, 0}$ is the O\&M cost for the FGD device, including limestone expense $\left(C_{\mathrm{OMS} 0,1}\right)$, process water expense $\left(C_{\mathrm{OMS} 0,2}\right)$, effluent processing expense $\left(C_{\mathrm{OMSO}, 3}\right)$ and equipment maintenance expense $\left(C_{\mathrm{OMSO}, 4}\right)$. Personnel wages, depreciation cost, amortization cost and electricity consumption cost for the De-SO ${ }_{x}$ device and the following De- $\mathrm{NO}_{x}$ device are considered from the viewpoint of the whole power plant. Furthermore, $C_{\mathrm{OMS} 0,1}=c_{\mathrm{CaCO}_{3}} \times S_{\mathrm{ar}} \times M_{\mathrm{F}, 0} \times H_{\mathrm{n}} / H_{\mathrm{i}} \times W \times H \times$ $100 / 32 \times r_{\mathrm{Ca}_{2} \mathrm{~S}} / P_{\mathrm{CaCO}_{3}}$, in which, $H_{\mathrm{n}}$ is the lower heating value of the standard coal, $29270 \mathrm{~kJ} / \mathrm{kg}, c_{\mathrm{CaCO}_{3}}$ is the unit price of limestone (60 $¥ / \mathrm{t}[11]), r_{\mathrm{CaCO}_{3}}$ is the mole ratio of $\mathrm{Ca}$ to $\mathrm{S}$ (1.03 [14]), $P_{\mathrm{CaCO}_{3}}$ is the purity of limestone (90\% [14]); $C_{\mathrm{OMS} 0,2}=c_{\mathrm{pw}} \times M_{\mathrm{pw}, 0} \times H$, where $c_{\mathrm{pw}}$ is the unit price of process water (1.54¥/t [14]), $M_{\mathrm{pw}, 0}$ is the process water consumption rate $\left(10 \mathrm{t} / \mathrm{h}\right.$ [14] for the $2 \times 300 \mathrm{MW}$ power plant); $C_{\mathrm{OMS} 0,3}=$ $c_{\mathrm{ef}} \times M_{\mathrm{ef}, 0} \times H$, where $c_{\mathrm{ef}}$ is the unit effluent processing cost $(1.6 ¥ / \mathrm{t}[14]), M_{\mathrm{ef}, 0}$ is the effluent discharge rate $(120 \mathrm{t} / \mathrm{h}$ [14] for the $2 \times 300 \mathrm{MW}$ power plant); $C_{\mathrm{OMS} 0,4}=C_{\mathrm{IT}, \mathrm{S}, 0} \times p_{\mathrm{OM}, \mathrm{S}, 0}$, $p_{\mathrm{OM}, \mathrm{S}, 0}$ is the O\&M coefficient (1.5\% [14], including the major maintenance expense) for the $\mathrm{De}-\mathrm{SO}_{x}$ device. And for the $2 \times 600 \mathrm{MW}$ supercritical and $2 \times 1000 \mathrm{MW}$ ultra-supercritical power plants, the $C_{\mathrm{OMS} 0,2}$ and $C_{\mathrm{OMS} 0,3}$ are proportional to the limestone consumption rate in each power plant, respectively. $C_{\mathrm{OM}, \mathrm{S}, 0}$ is the O\&M cost for the SCR device, including ammonia expense, catalyst expense, steam expense and equipment maintenance expense [15,16]. Adjusted for the annual operation hours, the ammonia expense, catalyst expense and steam expense for the $2 \times 300 \mathrm{MW}$ power plant considered in this paper are 4.62, 13.34 and $0.11 \mathrm{M} ¥ / \mathrm{y}$, respectively [16]. The corresponding data for the $2 \times 600 \mathrm{MW}$ power plant are $9.15,26.43$ and $0.22 \mathrm{M} ¥ \mathrm{y}$, respectively [15]. However, because $2 \times 1000 \mathrm{MW}$ ultra-supercritical power plants with SCR devices are very limited in China, data for this size of SCR device is very difficult to obtain. In this paper, the corresponding data for the $2 \times 1000 \mathrm{MW}$ power plant (14, 40.42 and $0.35 \mathrm{M} ¥ / \mathrm{y}$, respectively) were proportional to those of the $2 \times 600 \mathrm{MW}$ power plant. The O\&M coefficient of the SCR device used in this paper is $1.5 \%$.

(4) Depreciation cost

$$
C_{4,0}=C_{\mathrm{IT}, 0} \times p_{\mathrm{fa}} \times\left(1-p_{\mathrm{lv}}\right) / Y_{\mathrm{d}},
$$

in which, $p_{\mathrm{fa}}$ is the fixed assets formation percentage $(95 \%$ [11]), $p_{\mathrm{lv}}$ is the residual value percentage (5\% [11]) and the $Y_{\mathrm{d}}$ is the depreciation period (15 years).

(5) Amortization cost

$$
C_{5,0}=C_{\text {IT }, 0} \times p_{\text {ia }} / Y_{\mathrm{a}},
$$

in which $p_{\text {ia }}$ is the percentage of intangible and deferred assets (5\%) [17] and $Y_{\mathrm{a}}$ is the amortization period (5 years).

(6) Pollutants emission tax

$$
C_{6,0}=E_{\mathrm{S}, 0} \times T_{\mathrm{S}}+E_{\mathrm{N}, 0} \times T_{\mathrm{N}},
$$

in which $E_{\mathrm{S}, 0}$ is the $\mathrm{SO}_{2}$ emission amount in the conventional power plant, which can be estimated by referring to [18]. $E_{\mathrm{S}, 0}=32 / 16 \times m_{\mathrm{F}, 0} \times H_{\mathrm{n}} / H_{\mathrm{i}} \times W \times H \times S_{\mathrm{ar}} \times t_{\mathrm{S}, 0} \times\left(1-\eta_{\mathrm{S}, 0}\right)$, where $t_{\mathrm{S}, 0}$ is the ratio of $\mathrm{S}_{\mathrm{ar}}$ transformed to $\mathrm{SO}_{2}$ after coal combustion (80\% [18]); $E_{\mathrm{N}, 0}$ is the $\mathrm{NO}_{x}$ emission amount in the conventional power plant, $E_{\mathrm{N}, 0}=30.8 / 14 \times m_{\mathrm{F}, 0} \times W \times$ $H_{\mathrm{n}} / H_{\mathrm{i}} \times H \times N_{\mathrm{ar}} \times \eta_{\mathrm{n}, 0} / m_{\mathrm{n}, 0} \times\left(1-\eta_{\mathrm{N}, 0}\right)$, in which $30.8 / 14$ is the ratio of $\mathrm{NO}_{x}\left(95 \mathrm{~m} \% \mathrm{NO}\right.$ and $\left.5 \mathrm{~m} \% \mathrm{~N}_{2} \mathrm{O}\right)$ molecular weight to that of $\mathrm{N}$ element [18], $\eta_{\mathrm{N}, 0}$ is the transforming rate $(25 \%$ [18]) of fuel $\mathrm{N}, m_{\mathrm{n}, 0}$ is the percentage of $\mathrm{NO}_{x}$ coming from fuel $\mathrm{N}$ to total $\mathrm{NO}_{x}\left(80 \%\right.$ [18]), $T_{\mathrm{S}}$ and $T_{\mathrm{N}}$ are the unit pollutant emission tax $(0.6 ¥ / 0.95 \mathrm{~kg})$ for $\mathrm{SO}_{2}$ and $\mathrm{NO}_{x}$, respectively. In addition, pollutant emission taxes for $\mathrm{CO}$ and particles were not considered in this paper and tax differences from different regions and environment functions were also not considered. If the emission tax of $\mathrm{CO}_{2}$ is considered, then eq. (8) should be modified to be

$$
C_{6,0}=E_{\mathrm{S}, 0} \times T_{\mathrm{S}}+E_{\mathrm{N}, 0} \times T_{\mathrm{N}}+E_{\mathrm{CO}_{2}, 0} \times T_{\mathrm{CO}_{2}},
$$

in which, $E_{\mathrm{CO}_{2}, 0}$ is the $\mathrm{CO}_{2}$ emission amount, $E_{\mathrm{CO} 2,0}=44 / 12$ $\times m_{\mathrm{F}, 0} \times H_{\mathrm{n}} / H_{\mathrm{i}} \times W \times H \times \mathrm{C}_{\mathrm{ar}} \times t_{\mathrm{C}} \times\left(1-\eta_{\mathrm{C}, 0}\right)$, and $T_{\mathrm{CO}_{2}}$ is the unit $\mathrm{CO}_{2}$ emission tax (¥/t), $t_{\mathrm{C}}$ is the ratio of $\mathrm{C}_{\mathrm{ar}}$ transformed to be $\mathrm{CO}_{2}$ after coal combustion (usually $100 \%$ ), $\eta_{\mathrm{C}, 0}$ is the $\mathrm{CO}_{2}$ capture ratio (for conventional plants, $\eta_{\mathrm{C}, 0}=0$; and for 
oxy-combustion plants, $\left.\eta_{\mathrm{C}, 1}=90 \%\right)$.

(7) Personnel wages

$$
C_{7,0}=\left(N_{\text {base }, 0}+N_{\mathrm{S}, 0}+N_{\mathrm{N}, 0}\right) \times c_{\text {pay }} \times\left(1+r_{\mathrm{w}}\right),
$$

in which, $N_{\text {base }, 0}, N_{\mathrm{S}, 0}, N_{\mathrm{N}, 0}$ are personnel numbers for the base power plant, the FGD system and the SCR system, respectively. For the three kinds of plant, $N_{\text {base }, 0}$ is 234,247 and 300 [11], respectively; $N_{\mathrm{S}, 0}$ is $15,18,21$ (three groups, and each of 5, 6 and 7 persons), respectively; $N_{\mathrm{N}, 0}$ is 15,18 , 21 (three groups, and each of 5, 6 and 7 persons), respectively. $c_{\text {pay }}$ is the annual wage for each person $(50000 ¥ / y)$, and $r_{\mathrm{w}}$ is the welfare and labor insurance coefficient $(60 \%$ [11]).

(8) Material cost

$$
C_{8,0}=p_{\mathrm{m}, 0} \times W \times H,
$$

in which, $p_{\mathrm{m}, 0}$ is the material cost ratio $(6,5,4 ¥ /(\mathrm{MW} \mathrm{h})$ [11] for each plant, respectively).

(9) Other costs

$$
C_{9,0}=p_{\mathrm{o}, 0} \times W \times H,
$$

in which, $p_{\mathrm{o}, 0}$ is the other costs ratio $(12,10,8 ¥ /(\mathrm{MW} \mathrm{h})$ [11] for each plant, respectively).

(10) By-products revenue

$$
C_{10,0}=M_{\mathrm{CaSO}_{4}} \times c_{\mathrm{CaSO}_{4}},
$$

in which, $M_{\mathrm{CaSO}_{4}}=S_{\mathrm{ar}} \times M_{\mathrm{F}, 0} \times H_{\mathrm{n}} / H_{\mathrm{i}} \times W \times H \times \eta_{\mathrm{S}, 0} \times 172 / 32 /$ $P_{\mathrm{CaSO}_{4}}, P_{\mathrm{CaSO}_{4}}$ is the purity of gypsum (90\% [14], viz. $10 \%$ water content), and $c_{\mathrm{CaSO}_{4}}$ is the market price of gypsum (50 $¥ / \mathrm{t}$ ). It should be mentioned that it is only the revenue for gypsum (by-product from desulfurization) that was considered for conventional plants in this paper.

(ii) Cost calculation for oxy-combustion power plants. We can calculate the $C_{\mathrm{T}}$ in oxy-combustion plants similarly to that of the conventional plants, and the differences lie in the boiler retrofit, ASU and CPU additions. Also, the De$\mathrm{SO}_{x}$ and De- $\mathrm{NO}_{x}$ devices can be simplified significantly in the oxy-combustion plants. Because of the $\mathrm{N}_{2}$-lean combustion environment and flue gas recycle, a lower cost De-SO technology (such as limestone injection into the furnace and the activation of unreacted calcium, LIFAC) could be adopted to reach a satisfactory De-SO ${ }_{x}$ result. In addition, $\mathrm{SO}_{x}$ in the flue gas can also be removed in the CPU, thus a total $95 \%$ De-SO $\mathrm{S}_{x}$ efficiency was used in this paper. On the other hand, because of the $\mathrm{N}_{2}$-lean environment, it can be considered that there is only fuel $\mathrm{NO}_{x}$ generated (viz. $m_{\mathrm{n}, 1}=$ $100 \%$ ) and at the same time, the flue gas recycle, low air excess factor (tiny positive pressure combustion, air excess factor $\alpha_{1}=1.05$ ) and adopting low $\mathrm{NO}_{x}$ air staging burners can effectively suppress the fuel $\mathrm{NO}_{x}$ generation (considering the fuel $\mathrm{N}$ transforming efficiency $\eta_{\mathrm{n}, 1}$ is $15 \%$ ). Also, $\mathrm{NO}_{x}$ in the flue gas can be co-removed in the CPU (assuming the De- $\mathrm{NO}_{x}$ efficiency $\eta_{\mathrm{N}, 1}=30 \%$ ), so an additional
SCR is not needed. In general, costs for the oxy-combustion plants can be calculated as follows:

(1) Because the flue gas recycle can effectively reduce the heat loss from the flue gas, the efficiency increase ratio $\eta_{\mathrm{e}}=\eta_{b} /\left(\eta_{b}+0.02\right)$ is applicable, and this reduces coal consumption. The unit standard coal consumption rate in the oxy-combustion plant is $m_{\mathrm{F}, 1}=m_{\mathrm{F}, 0} \times \eta_{\mathrm{e}}$, and its fuel cost $C_{1,1}=C_{1,0} \times \eta_{\mathrm{e}}$. The boiler efficiencies $\left(\eta_{b}\right)$ for the three kinds of plant are set to be $92 \%, 94 \%$ and $95 \%$, respectively.

(2) The total investment cost $\left(C_{\mathrm{IT}, 1}\right)$ for oxy-combustion plants can be calculated as

$$
\begin{aligned}
C_{\mathrm{IT}, 1}= & C_{\mathrm{IT}, \text { base }, 0}+C_{\mathrm{I}, \text { bioler }, 0} \times 7 \%+C_{\mathrm{IT}, \mathrm{S}, 0} / 3+C_{\mathrm{ASU}} \\
& +C_{\mathrm{IT}, \text { base }, 0} \times 2.5 \%,
\end{aligned}
$$

in which, the second item on the right side of the equation is the boiler retrofit cost, which can be estimated to be $7 \%$ [12] of the boiler cost $\left(C_{\mathrm{I}, \text { bioler, } 0}\right)$, and the $C_{\mathrm{I}, \mathrm{bioler}, 0}$ for the three sizes of boilers are $652.75,1299.9$ and 2800 M¥ [11], respectively; the third item on the right side is the cost of the LIFAC De-SO ${ }_{x}$ device, which is assumed to be $1 / 3$ of that of the FGD; while the fourth item is the cost of the ASU. According to the investigation data from some oxygen production companies (such as Hangzhou Oxygen Production and the Sichuan Air Separation), the investment cost of large-scale oxygen production machines $\left(60000 \mathrm{~N} \mathrm{~m}^{3} / \mathrm{h}\right)$ satisfying the oxygen concentration demand of oxy-combustion technology is $120 \mathrm{M}$, and the actual oxygen consumption rate $\left(\mathrm{N} \mathrm{m}^{3} / \mathrm{h}\right)$ for oxy-combustion is $V_{\mathrm{O}, 1}=v_{\mathrm{O}} \times \alpha_{1}$ $\times m_{\mathrm{F}, 1} \times W \times H_{\mathrm{n}} / H_{\mathrm{i}}$. Therefore, the $C_{\mathrm{ASU}}=V_{\mathrm{O}, 1} / 60000 \times 120 \mathrm{M} ;$ and the fifth item on the right side is the cost of the CPU, which is about $2.5 \%$ of the total investment cost of the whole base power plant [13]. Similar to that of the base plant, and the loan interest cost, depreciation cost and amortization cost can be calculated based on the $C_{\mathrm{IT}, 1}$.

(3) The O\&M cost of the oxy-combustion plant includes the O\&M cost of the base plant (excluding De-SO $\mathrm{S}_{x}$ device, ASU and CPU), the O\&M cost of the De-SO ${ }_{x}$ device, the O\&M cost of ASU and the O\&M cost of CPU, can be estimated as

$$
\begin{aligned}
C_{3,1}= & \left(C_{\mathrm{IT}, \text { base }, 0}+C_{\mathrm{I}, \text { bioler }, 0} \times 7 \%\right) \times p_{\mathrm{OM}, \text { base }, 1}+C_{\mathrm{OM}, \mathrm{S}, 0} / 3+C_{\mathrm{ASU}} \\
& \times p_{\mathrm{OM}, \mathrm{ASU}}+C_{\mathrm{IT}, \text { base }, 0} \times 2.5 \% \times p_{\mathrm{OM}, \mathrm{CPU}},
\end{aligned}
$$

in which, $p_{\mathrm{OM}, \mathrm{base}, 1}$ is the O\&M coefficient of the oxycombustion base plant (also 2.5\%, including the major maintenance expense); the O\&M cost of the De-SO $\mathrm{S}_{x}$ device (LIFAC) is set to be $1 / 3$ of that of FGD; $p_{\mathrm{OM}, \mathrm{ASU}}$ is the O\&M coefficient of ASU $(1.5 \%)$ and the $p_{\mathrm{OM}, \mathrm{CPU}}$ is the O\&M coefficient of CPU (1.5\%).

(4) Each pollutant emission amount and corresponding emission tax can be estimated by using methods introduced for conventional power plants.

(5) The personnel wages for an oxy-combustion base plant (including LIFAC) are considered to be equivalent to 
that of the conventional plant.

(6) The material cost ratio and other cost ratios in oxycombustion plants are equivalent to that of conventional plants.

(7) There is no gypsum revenue in oxy-combustion plants, but the high purity $\mathrm{CO}_{2}$ may be considered as a product. So in that case, the by-products revenue could be $C_{10,1}=M_{\mathrm{CO}_{2}} \times c_{\mathrm{CO}_{2}}$, in which $\mathrm{CO}_{2}$ capture amount $M_{\mathrm{CO}_{2}}=\mathrm{C}_{\mathrm{ar}}$ $\times m_{\mathrm{F}, 1} \times H_{\mathrm{n}} / H_{\mathrm{i}} \times H \times W \times \eta_{\mathrm{C}} \times 44 / 12$, and $c_{\mathrm{CO}_{2}}$ is the unit price of $\mathrm{CO}_{2}$ product.

\subsection{Cost of electricity}

The cost of electricity $\left(c_{\mathrm{COE}}\right)$ for coal-fired power plants can be calculated as

$$
c_{\mathrm{COE}}=C_{\mathrm{T}} /\left(W_{\mathrm{net}} \times H\right),
$$

in which, $W_{\text {net }}$ is the net power output. For conventional power plants, $W_{\text {net }, 0}=W \times\left(1-r_{\mathrm{pe}, 0}\right)-W_{\mathrm{S}, 0}-W_{\mathrm{N}, 0}, r_{\mathrm{pe}, 0}$ is the auxiliary power ratio $(5.5 \%, 5.2 \%$ and $4.5 \%$ [11] for the three sizes of plant, respectively), $W_{\mathrm{S}, 0}$ is the power consumption of the De-SO $\mathrm{S}_{x}$ device $(1.5 \%, 1.1 \%$ and $0.7 \%$ [11] of the total load, respectively), $W_{\mathrm{N}, 0}$ is the power consumption of the De- $\mathrm{NO}_{x}$ device $(1.3,1.6$ and 2.0 MW [15,16], respectively). For oxy-combustion power plants, $W_{\text {net, } 1}=W$ $\times\left(1-r_{\mathrm{pe}, 1}\right)-W_{\mathrm{S}, 1}-W_{\mathrm{ASU}}-W_{\mathrm{CPU}}, r_{\mathrm{pe}, 1}$ is equivalent to $r_{\mathrm{pe}, 0}$, the power consumption of the De-SO ${ }_{x}$ device is $W_{\mathrm{S}, 1}=W_{\mathrm{S}, 0} / 3$, the power consumption of $\mathrm{ASU}$ is $W_{\mathrm{ASU}}=V_{\mathrm{O}, 1} / 60000 \times 21$ MW (the power consumption of the $60000 \mathrm{Nm}^{3} / \mathrm{h} \mathrm{ASU}$ is $21 \mathrm{MW}$ ) and the power consumption of CPU, $W_{\mathrm{CPU}}$, is estimated to be $8 \%$ [13] of the gross power output.

The $c_{\mathrm{COE}}$ values of the conventional (four cases: without $\mathrm{De}-\mathrm{SO}_{x}$ or De-NO $\mathrm{NO}_{x}$ device; with De-SO ${ }_{x}$ device; with De$\mathrm{NO}_{x}$ device; with De-SO $\mathrm{S}_{x}$ and De-NO $\mathrm{NO}_{x}$ devices) and oxycombustion plants (two cases: with LIFAC and without De$\mathrm{SO}_{x}$ device, the $\mathrm{CO}_{2}$ tax and the $\mathrm{CO}_{2}$ sale price are not considered) under the three different loads are listed in Table 2. Figure 2 gives a comparison of the $c_{\mathrm{COE}}$ in different cases.

The results in Table 2 and Figure 2 show that (the descriptions in the following paragraph all correspond to the 2 $\times 300$ MW subcritical, $2 \times 600$ MW supercritical and $2 \times$ $1000 \mathrm{MW}$ ultra-supercritical plants sequentially):

(1) The $c_{\mathrm{COE}}$ ranges for conventional power plants are 341.04-358.72, 310.57-324.50 and 280.19-290.12 ¥/(MW h), respectively. The $c_{\mathrm{COE}}$ increases $5.18 \%, 4.49 \%$ and $3.54 \%$ if the De-SO $\mathrm{SO}_{x}$ and De- $\mathrm{NO}_{x}$ devices are added. In comparison to the conventional power plants with De-SO $\mathrm{S}_{x}$ and De-NO $\mathrm{NO}_{x}$ devices, the $c_{\mathrm{COE}}$ of oxy-combustion plants (with LIFAC) increase $39.4 \%, 38.39 \%$ and $36.47 \%$, respectively. The investor's profit-sharing and income tax were not considered during the $c_{\mathrm{COE}}$ calculation. This part of the cost accounts

Table 2 Techno-economic analysis results for different plants under three loads

\begin{tabular}{|c|c|c|c|c|c|c|c|}
\hline Plant & $\begin{array}{c}c_{\mathrm{COE}} \\
(¥ /(\mathrm{MW} \mathrm{h}))\end{array}$ & $\begin{array}{c}C_{\mathrm{IT}} \\
(\mathrm{M}) \\
\end{array}$ & $\begin{array}{c}C_{\mathrm{T}} \\
(\mathrm{M} / \mathrm{y})\end{array}$ & $\begin{array}{c}W_{\text {net }} \\
(\mathrm{MW})\end{array}$ & $\begin{array}{l}\mathrm{SO}_{x} \text { capture/ } \\
\text { emission }(\mathrm{t} / \mathrm{y})\end{array}$ & $\begin{array}{l}\mathrm{NO}_{x} \text { capture/ } \\
\text { emission }(\mathrm{t} / \mathrm{y})\end{array}$ & $\begin{array}{l}\mathrm{CO}_{2} \text { capture/ } \\
\text { emission }(\mathrm{t} / \mathrm{y})\end{array}$ \\
\hline \multicolumn{8}{|l|}{$2 \times 300 \mathrm{MW}$ subcritical } \\
\hline Conventional (no FGD or SCR) & 341.04 & 2647.2 & 966.86 & 567 & $0 / 8358.3$ & $0 / 5846.56$ & $0 / 2695431.08$ \\
\hline Conventional (FGD, no SCR) & 349.36 & 2786.49 & 974.72 & 558 & $7940.39 / 417.92$ & $0 / 5846.56$ & $0 / 2695431.08$ \\
\hline Conventional (SCR, no FGD) & 350.23 & 2738.44 & 990.63 & 565.7 & $0 / 8358.3$ & $4677.25 / 1169.31$ & $0 / 2695431.08$ \\
\hline Conventional (FGD and SCR) & 358.72 & 2877.72 & 998.49 & 556.7 & $7940.39 / 417.92$ & $4677.25 / 1169.31$ & $0 / 2695431.08$ \\
\hline Oxy-combustion (no LIFAC) & 495.06 & 3391.13 & 1010.88 & 408.39 & $3343.32 / 5014.98$ & $748.36 / 1122.54$ & $2374273.33 / 263808.15$ \\
\hline Oxy-combustion (with LIFAC) & 500.04 & 3437.56 & 1013.56 & 405.39 & $7940.39 / 417.92$ & $748.36 / 1122.54$ & $2374273.33 / 263808.15$ \\
\hline \multicolumn{8}{|l|}{$2 \times 600 \mathrm{MW}$ supercritical } \\
\hline Conventional (no FGD or SCR) & 310.57 & 4410 & 1766.53 & 1137.6 & $0 / 15867.51$ & 0/11099.18 & $0 / 5117040.59$ \\
\hline Conventional (FGD, no SCR) & 316.38 & 4641.81 & 1778.70 & 1124.4 & $15074.13 / 793.38$ & 0/11099.18 & $0 / 5117040.59$ \\
\hline Conventional (SCR, no FGD) & 318.59 & 4545 & 1809.59 & 1136 & $0 / 15867.51$ & $8879.35 / 2219.84$ & $0 / 5117040.59$ \\
\hline Conventional (FGD and SCR) & 324.50 & 4776.81 & 1821.76 & 1122.8 & $15074.13 / 793.38$ & $8879.35 / 2219.84$ & $0 / 5117040.59$ \\
\hline Oxy-combustion (no LIFAC) & 445.86 & 5811.70 & 1853.69 & 831.52 & $6347.00 / 9520.50$ & $1420.70 / 2131.04$ & $4509392.02 / 501043.56$ \\
\hline Oxy-combustion (with LIFAC) & 449.09 & 5888.97 & 1857.26 & 827.12 & $15074.13 / 793.38$ & $1420.70 / 2131.04$ & $4509392.02 / 501043.56$ \\
\hline \multicolumn{8}{|l|}{$2 \times 1000 \mathrm{MW}$ ultra-supercritical } \\
\hline Conventional (no FGD or SCR) & 280.19 & 7182 & 2675.81 & 1910 & $0 / 24323.10$ & $0 / 17013.80$ & $0 / 7843847.06$ \\
\hline Conventional (FGD, no SCR) & 283.20 & 7429.09 & 2684.76 & 1896 & $23106.95 / 1216.16$ & $0 / 17013.80$ & $0 / 7843847.06$ \\
\hline Conventional (SCR, no FGD) & 287.05 & 7357 & 2738.49 & 1908 & $0 / 24323.10$ & $13611.04 / 3402.76$ & $0 / 7843847.06$ \\
\hline Conventional (FGD and SCR) & 290.12 & 7604.09 & 2747.44 & 1894 & 23106.95/1216.16 & $13611.04 / 3402.76$ & $0 / 7843847.06$ \\
\hline Oxy-combustion (no LIFAC) & 394.37 & 9398.12 & 2815.60 & 1427.90 & $9729.24 / 14593.86$ & $2177.77 / 3266.65$ & $6913906.42 / 768211.82$ \\
\hline Oxy-combustion (with LIFAC) & 395.93 & 9480.48 & 2817.50 & 1423.23 & $23106.95 / 1216.16$ & $2177.77 / 3266.65$ & $6913906.42 / 768211.82$ \\
\hline
\end{tabular}




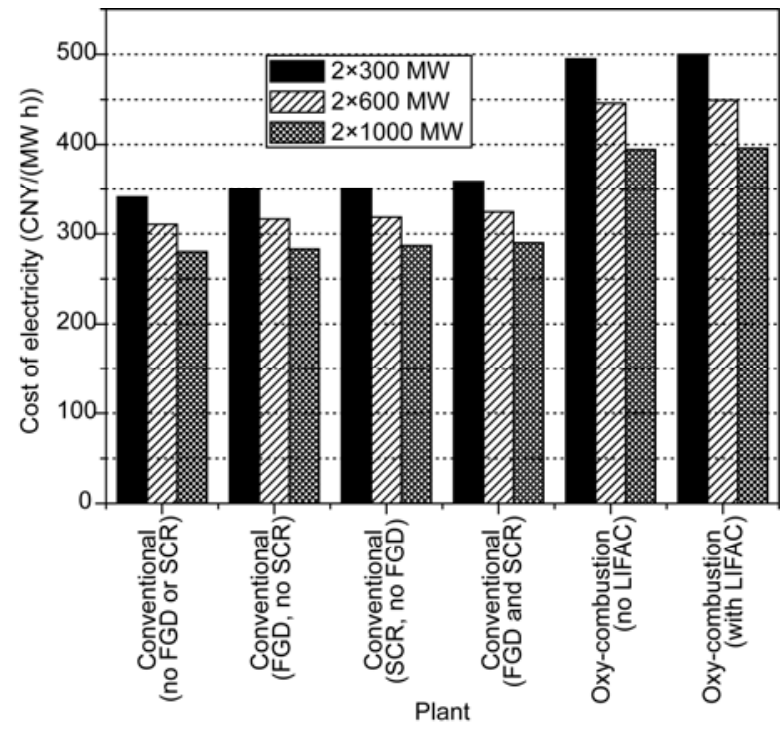

Figure 2 Costs of electricity for different cases.

for about $12 \%-14 \%$ [11] of the total $c_{\mathrm{COE}}$. If these effects are considered, the $c_{\mathrm{COE}}$ of conventional power plants are approximately the same according to the results presented in [11], which indicates that the techno-economic analysis performed in this paper is in reasonable agreement.

(2) The static investment cost increases by $8.7 \%, 8.32 \%$ and $5.88 \%$ if the De-SO ${ }_{x}$ and De- $\mathrm{NO}_{x}$ devices are added in the conventional power plants; in comparison to the conventional power plants with $\mathrm{De}-\mathrm{SO}_{x}$ and De- $\mathrm{NO}_{x}$ devices, the static investment costs for oxy-combustion plants (with LIFAC) increase by $19.45 \%, 23.28 \%$ and $24.68 \%$, respectively. From the subcritical to the supercritical and finally the ultra-supercritical, the material upgrade and some special imported parts make the boiler cost increase rapidly.

(3) Even if the De-SO $\mathrm{SO}_{x}$ and De- $\mathrm{NO}_{x}$ devices are not included in the oxy-combustion power plants, a low $\mathrm{SO}_{x}$ and $\mathrm{NO}_{x}$ emission level can still be achieved. However, if the LIFAC system is installed, the static investment costs of the oxy-combustion plants increase by only about $1 \%$, the annualized total costs remain nearly unchanged, power outputs decrease about $0.5 \%$ and $c_{\mathrm{COE}}$ increases no more than $1 \%$, and a De-SO ${ }_{x}$ efficiency similar to the FGD technology can be realized.

(4) The static investment costs for oxy-combustion plants increase mainly because of the high commercial price of ASU, and the investment in the CPU system. Further developments to the oxygen production technology and increasing the scale of the ASU market should decrease the costs of ASU systems significantly, and then the economic characteristics of the oxy-combustion technology will improve significantly.

(5) In comparison to the conventional power plants with De-SO $\mathrm{S}_{x}$ and De-NO $\mathrm{NO}_{x}$ devices, the annualized total costs for oxy-combustion plants (with LIFAC) increase by $1.51 \%$,
$1.95 \%$ and $2.55 \%$, respectively. The increases are slight because the De-SO $\mathrm{SO}_{x}$ and De-NO $\mathrm{NO}_{x}$ devices with high O\&M costs are removed and coal consumption decreases because of the enhanced boiler efficiency in oxy-combustion plants. However, the net power outputs for oxy-combustion plants decrease substantially in comparison to conventional plants because of the high power consumptions of ASU and CPU systems, which also increase the $c_{\mathrm{COE}}$ of oxy-combustion plants substantially. Therefore, developing low cost and low power consumption ASU and CPU systems is the key to enhance the economic characteristics of the oxy-combustion technology. The components and corresponding proportions of annualized total costs for three different load plants under conventional combustion and oxy-combustion are shown in Figure 3. The results show that fuel costs, the depreciation and amortization costs affect the distributions of the annualized total costs remarkably. Because the unit investment costs of base plants reduce sequentially from the subcritical plants to the supercritical plants and finally the ultra-supercritical plants, although the unit coal consumptions also reduce sequentially, the ratios of fuel costs increase sequentially, and are $64 \%, 67 \%$ and $68 \%$, respectively. Because the ASU and CPU systems are added in oxy-combustion plants, the ratios of investment costs and O\&M costs increase, accordingly, but the ratios of fuel costs reduce $2 \%-3 \%$. Also, it is worth emphasizing, the ratios of De-SO $\mathrm{S}_{x}$ and De- $\mathrm{NO}_{x}$ costs in oxy-combustion plants decrease greatly, and become almost negligible.

\section{$1.4 \mathrm{CO}_{2}$ avoidance cost}

Oxy-combustion technology has been considered to control the $\mathrm{CO}_{2}$ emission from fossil fuel combustion, and this is the reason why so much attention has been paid to it. The $\mathrm{CO}_{2}$ avoidance cost $\left(c_{\mathrm{CAC}}\right)$ can be used to evaluate the economic property of controlling the $\mathrm{CO}_{2}$ emission. $c_{\mathrm{CAC}}$ is defined as the ratio of the $c_{\mathrm{COE}}$ difference to the unit $\mathrm{CO}_{2}$ emission amounts difference between the $\mathrm{CO}_{2}$ emission control system (oxy-combustion plant with LIFAC in this paper) and the corresponding $\mathrm{CO}_{2}$ emission non-control system (conventional plant with De- $\mathrm{SO}_{x}$ and De- $\mathrm{NO}_{x}$ devices in this paper). It means the additional economic cost of avoiding one ton $\mathrm{CO}_{2}$ emission, which can be described as

$$
c_{\mathrm{CAC}}=\frac{c_{\mathrm{COE}, 1}-c_{\mathrm{COE}, 0}}{e_{\mathrm{CO}_{2}, 0}-e_{\mathrm{CO}_{2}, 1}}=\frac{c_{\mathrm{COE}, 1}-c_{\mathrm{COE}, 0}}{\frac{E_{\mathrm{CO}_{2}, 0}}{W_{\mathrm{net}, 0} H}-\frac{E_{\mathrm{CO}_{2}, 1}}{W_{\mathrm{net}, 1} H}},
$$

in which, $e_{\mathrm{CO}_{2}}$ is the $\mathrm{CO}_{2}$ emission amount per unit of power (t/MWh). The $c_{\mathrm{CAC}}$ of oxy-combustion plants (with LIFAC) for three different loads are given in Table 3.

Large amounts of $\mathrm{CO}_{2}$ emission can be reduced in oxy-combustion plants, producing an environmental benefit. Some countries have already begun to tax the $\mathrm{CO}_{2}$ emission 


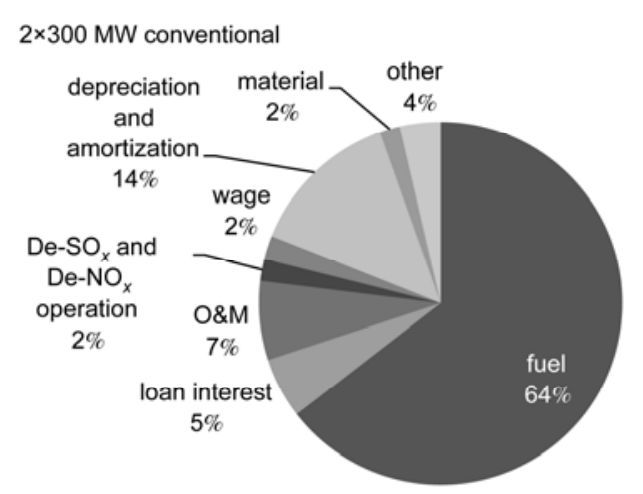

(a) $2 \times 300 \mathrm{MW}$, conventional (FGD and SCR)

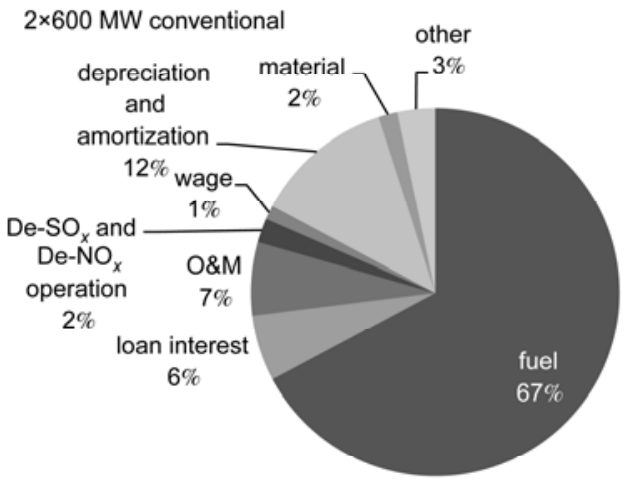

(c) $2 \times 600 \mathrm{MW}$ conventional (FGD and SCR)

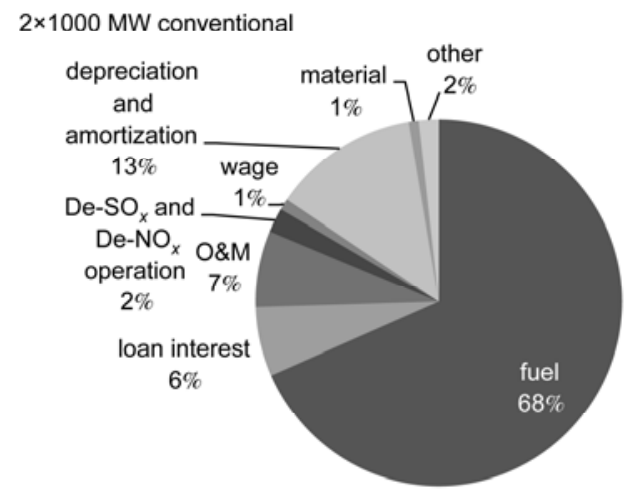

(e) $2 \times 1000 \mathrm{MW}$ conventional (FGD and SCR)

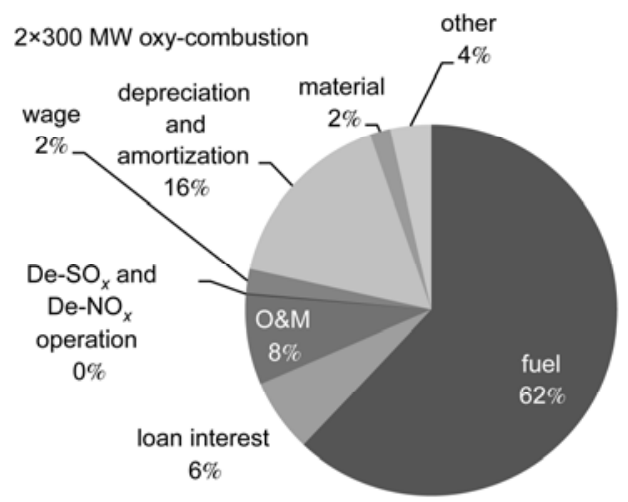

(b) $2 \times 300 \mathrm{MW}$ oxy-combustion (LIFAC)

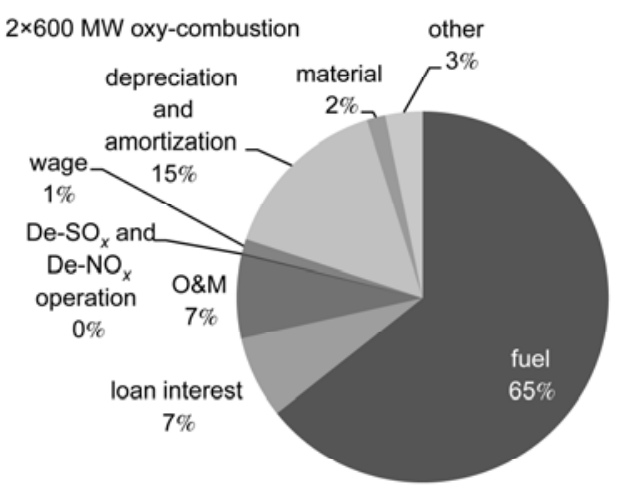

(d) $2 \times 600 \mathrm{MW}$ oxy-combustion (LIFAC)

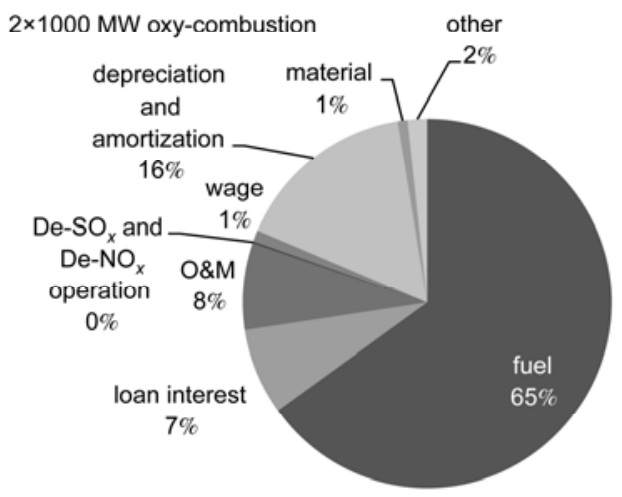

(f) $2 \times 1000 \mathrm{MW}$ oxy-combustion (LIFAC)

Figure 3 Structure diagrams of annualized total costs for three different load plants under conventional combustion and oxy-combustion.

Table $3 \quad c_{\mathrm{CAC}}$ and $c_{\mathrm{CCC}}$ for oxy-combustion plants

\begin{tabular}{cccc}
\hline Item & $2 \times 300 \mathrm{MW}$ & $2 \times 600 \mathrm{MW}$ & $2 \times 1000 \mathrm{MW}$ \\
\hline$c_{\mathrm{COE}, 1}(¥ /(\mathrm{MW} \mathrm{h}))$ & 500.04 & 449.09 & 395.93 \\
$c_{\mathrm{COE}, 0}(¥ /(\mathrm{MW} \mathrm{h}))$ & 358.72 & 324.50 & 290.12 \\
$e_{\mathrm{CO} 2,0}(\mathrm{t} /(\mathrm{MW} \mathrm{h}))$ & 0.97 & 0.91 & 0.83 \\
$e_{\mathrm{CO} 2,1}(\mathrm{t} /(\mathrm{MW} \mathrm{h}))$ & 0.13 & 0.12 & 0.11 \\
$m_{\mathrm{CO} 2,1}(\mathrm{t} /(\mathrm{MW} \mathrm{h}))$ & 0 & 0 & 0 \\
$m_{\mathrm{CO} 2,0}(\mathrm{t} /(\mathrm{MWh}))$ & 1.17 & 1.09 & 0.97 \\
$c_{\mathrm{CAC}(¥ / \mathrm{t})}$ & 168.61 & 157.64 & 146.89 \\
$c_{\mathrm{CCC}(¥ / \mathrm{t})}$ & 120.65 & 114.26 & 108.90 \\
\hline
\end{tabular}

from conventional power plants. The $\mathrm{CO}_{2}$ tax has a significant influence on the economic performance of conventional and oxy-combustion plants, and the cost of electricity $\left(c_{\mathrm{COE}}^{\prime}\right)$ and $\mathrm{CO}_{2}$ avoidance cost $\left(c_{\mathrm{CAC}}^{\prime}\right)$ when considering the $\mathrm{CO}_{2}$ tax is

$$
\begin{gathered}
c_{\mathrm{COE}}^{\prime}=\frac{C_{\mathrm{T}}^{\prime}}{W_{\mathrm{net}} H}=\frac{C_{\mathrm{T}}+E_{\mathrm{CO}_{2}} T_{\mathrm{CO}_{2}}}{W_{\mathrm{net}} H} \\
=c_{\mathrm{COE}}+T_{\mathrm{CO}_{2}} e_{\mathrm{CO}_{2}}=c_{\mathrm{COE}}+\frac{E_{\mathrm{CO}_{2}} T_{\mathrm{CO}_{2}}}{W_{\mathrm{net}} H}, \\
c_{\mathrm{CAC}}^{\prime}=\frac{c_{\mathrm{COE}, 1}^{\prime}-c_{\mathrm{COE}, 0}^{\prime}}{e_{\mathrm{CO} 2,0}-e_{\mathrm{CO} 2,1}}=c_{\mathrm{CAC}}-T_{\mathrm{CO} 2} .
\end{gathered}
$$


Figure 4 shows the effect of the unit $\mathrm{CO}_{2}$ emission tax $\left(T_{\mathrm{CO}_{2}}\right)$ on the $c_{\mathrm{COE}}$ of conventional and oxy-combustion plants and the results show that the oxy-combustion technology could be competitive with the conventional mode if the $\mathrm{CO}_{2}$ emission is taxed at $140-170 ¥ / \mathrm{t}$. When the $T_{\mathrm{CO}_{2}}$ equals the $c_{\mathrm{CAC}}$ without $\mathrm{CO}_{2}$ emission taxation, the $c_{\mathrm{COE}}$ of the oxy-combustion plant is equivalent to that of the corresponding conventional plant. The $c_{\mathrm{CAC}}$ calculation relates to the $\mathrm{CO}_{2}$ emission reduction (the emission difference between the two plants), and the total tax cost difference of the two plants is also related to the $\mathrm{CO}_{2}$ emission reduction. This makes the $T_{\mathrm{CO}_{2}}$ value when the oxy-combustion plant and the corresponding conventional plant have equivalent economic property (named as critical $T_{\mathrm{CO}_{2}}$ ) is equal to the $c_{\mathrm{CAC}}$ without $\mathrm{CO}_{2}$ emission taxation (see equation (19) and Figure 4).

\section{$1.5 \mathrm{CO}_{2}$ capture cost}

Another parameter required to evaluate the economic property of the oxy-combustion technology is the $\mathrm{CO}_{2}$ capture cost $\left(c_{\mathrm{CCC}}\right) . c_{\mathrm{CCC}}$ is defined as the ratio of the $c_{\mathrm{COE}}$ difference to the unit $\mathrm{CO}_{2}$ capture amounts difference between the $\mathrm{CO}_{2}$ emission control system and the corresponding $\mathrm{CO}_{2}$ emission non-control system. It means the additional economic cost of capturing one ton $\mathrm{CO}_{2}$, can be described as

$$
c_{\mathrm{CCC}}=\frac{c_{\mathrm{COE}, 1}-c_{\mathrm{COE}, 0}}{m_{\mathrm{CO}_{2}, 1}-m_{\mathrm{CO}_{2}, 0}}=\frac{c_{\mathrm{COE}, 1}-c_{\mathrm{COE}, 0}}{m_{\mathrm{CO}_{2}, 1}}=\frac{c_{\mathrm{COE}, 1}-c_{\mathrm{COE}, 0}}{\frac{M_{\mathrm{CO}_{2}, 1} r_{\mathrm{CO}_{2}}}{W_{\mathrm{net}, 1} H}},
$$

in which, $m_{\mathrm{CO}_{2}}$ is the $\mathrm{CO}_{2}$ capture amount per unit of power $(\mathrm{t} /(\mathrm{MW} \mathrm{h})), r_{\mathrm{CO}_{2}}$ is the $\mathrm{CO}_{2}$ capture efficiency. The $c_{\mathrm{CCC}}$ of oxy-combustion plants (with LIFAC) for three different loads are also given in Table 3.

The high purity $\mathrm{CO}_{2}$ captured from oxy-combustion plants can be used in enhancing oil recovery (EOR), carbon

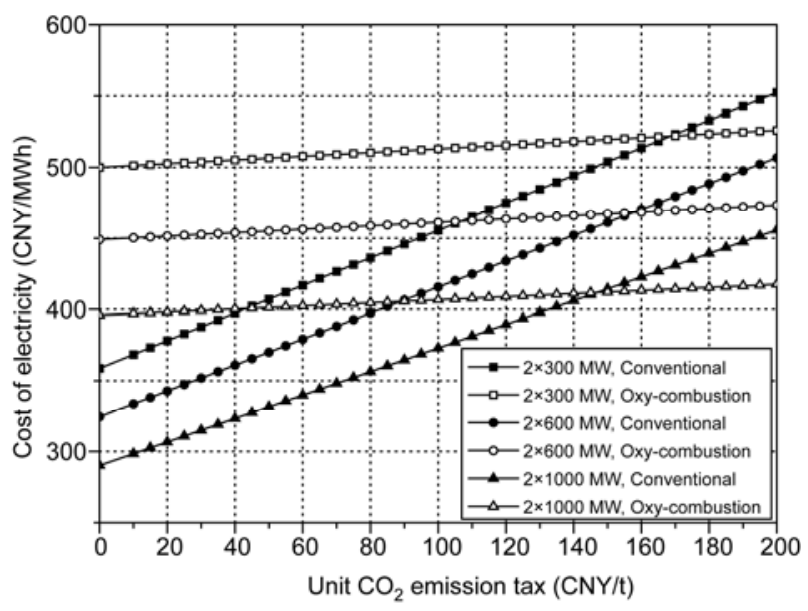

Figure 4 Relations between $c_{\mathrm{COE}}$ and $T_{\mathrm{CO}_{2}}$. fertilizer and beverage production. Therefore, if the $\mathrm{CO}_{2}$ sale is considered, the $c_{\mathrm{COE}}$ of oxy-combustion plants may be further reduced and the $\mathrm{CO}_{2}$ capture cost will change. The cost of electricity $\left(c_{\mathrm{COE}}^{\prime \prime}\right)$ and the $\mathrm{CO}_{2}$ capture cost $\left(c_{\mathrm{CCC}}^{\prime \prime}\right)$ when considering the $\mathrm{CO}_{2}$ sale are

$$
\begin{gathered}
c_{\mathrm{COE}}^{\prime \prime}=C_{\mathrm{T}}^{\prime \prime} /\left(W_{\mathrm{net}} H\right)=\left(C_{\mathrm{T}}-M_{\mathrm{CO}_{2}} c_{\mathrm{CO}_{2}}\right) /\left(W_{\mathrm{net}} H\right) \\
=c_{\mathrm{COE}}-c_{\mathrm{CO}_{2}} m_{\mathrm{CO}_{2}}=c_{\mathrm{COE}}-M_{\mathrm{CO}_{2}} c_{\mathrm{CO}_{2}} /\left(W_{\mathrm{net}} H\right) \\
c_{\mathrm{CCC}}^{\prime \prime}=\frac{c_{\mathrm{COE}, 1}^{\prime \prime}-c_{\mathrm{COE}, 0}^{\prime \prime}}{m_{\mathrm{CO}_{2}, 1}}=c_{\mathrm{CCC}}-c_{\mathrm{CO}_{2}} .
\end{gathered}
$$

The $\mathrm{CO}_{2}$ capture cost is related to the $\mathrm{CO}_{2}$ capture amount, and the $\mathrm{CO}_{2}$ sale revenue equals the $\mathrm{CO}_{2}$ capture amount multiplied by the unit $\mathrm{CO}_{2}$ sale price $\left(c_{\mathrm{CO}_{2}}\right)$. From eq. (22), we can see that the critical $c_{\mathrm{CO}_{2}}$ equals the $c_{\mathrm{CCC}}$ without a $\mathrm{CO}_{2}$ sale. Figure 5 shows the effect of the $c_{\mathrm{CO}_{2}}$ on the $c_{\mathrm{COE}}$ of conventional and oxy-combustion plants. Obviously, the economic characteristics of the oxy-combustion technology will enhance significantly if there are organizations who will purchase the high purity $\mathrm{CO}_{2}$ product. The critical $c_{\mathrm{CO} 2}$ (viz. $c_{\mathrm{CCC}}$ ) that makes the $c_{\mathrm{COE}}$ of oxy- combustion plants equivalent to those of conventional plants is $110-120 ¥ / \mathrm{t}$.

It is worth noting that the relative $\mathrm{CO}_{2}$ emission amounts $\left(e_{\mathrm{CO}_{2}, 0}-e_{\mathrm{CO}_{2}, 1}\right)$ and relative $\mathrm{CO}_{2}$ capture amounts $\left(m_{\mathrm{CO}_{2}, 1}-\right.$ $\left.m_{\mathrm{CO}_{2}, 0}\right)$ are not equivalent when the oxy-combustion plants are compared with conventional plants. This is because the thermal efficiencies of the oxy-combustion plant increase, and there is increased $\mathrm{CO}_{2}$ emitted from oxy-combustion plants. The non-equivalence between the relative $\mathrm{CO}_{2}$ emission amount and relative $\mathrm{CO}_{2}$ capture amount (the relative $\mathrm{CO}_{2}$ emission amount is generally less than the relative $\mathrm{CO}_{2}$ capture amount) leads to non-equivalence between the critical $T_{\mathrm{CO}_{2}}$ and the critical $c_{\mathrm{CO}_{2}}$, and the critical $T_{\mathrm{CO}_{2}}$ is generally greater than the critical $c_{\mathrm{CO}_{2}}$.

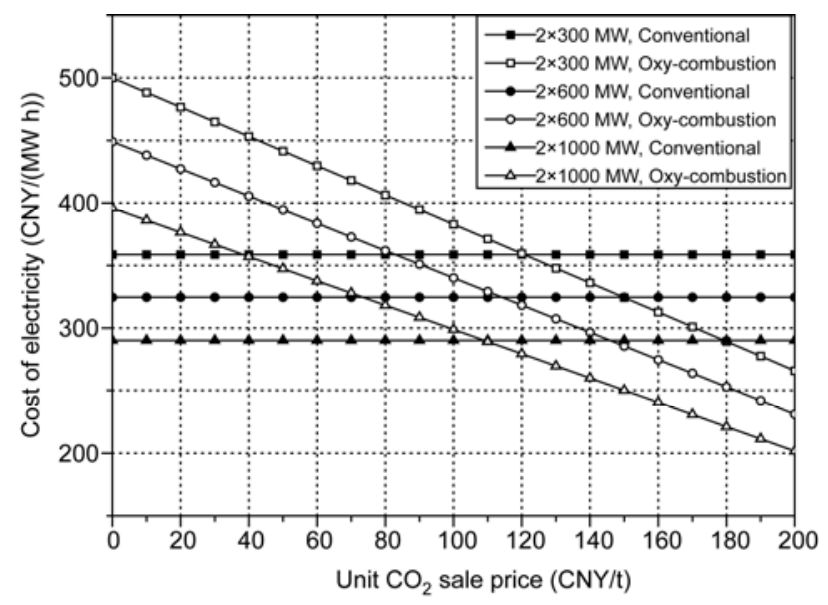

Figure 5 Relations between $c_{\mathrm{COE}}$ and $c_{\mathrm{CO}_{2}}$. 


\section{6 $\mathrm{CO}_{2}$ tax and $\mathrm{CO}_{2}$ sale}

The economic characteristics of the oxy-combustion technology were evaluated when the $\mathrm{CO}_{2}$ tax and the $\mathrm{CO}_{2}$ sale were considered together. Both the $\mathrm{CO}_{2}$ tax and the $\mathrm{CO}_{2}$ sale price significantly affect the $c_{\mathrm{COE}}, c_{\mathrm{CAC}}$ and $c_{\mathrm{CCC}}$ of oxycombustion plants. If they are considered together, the cost of electricity $\left(c_{\mathrm{COE}}^{\prime \prime \prime}\right), \mathrm{CO}_{2}$ avoidance cost $\left(c_{\mathrm{CAC}}^{\prime \prime \prime}\right)$ and $\mathrm{CO}_{2}$ capture cost $\left(c_{\mathrm{CCC}}^{\prime \prime}\right)$ are given by

$$
\begin{aligned}
& c_{\mathrm{COE}}^{\prime \prime \prime}=C_{\mathrm{T}}^{\prime \prime \prime} /\left(W_{\mathrm{net}} H\right) \\
& =\left(C_{\mathrm{T}}+E_{\mathrm{CO}_{2}} T_{\mathrm{CO}_{2}}-M_{\mathrm{CO}_{2}} c_{\mathrm{CO}_{2}}\right) /\left(W_{\text {net }} H\right) \\
& =c_{\mathrm{COE}}+T_{\mathrm{CO}_{2}} e_{\mathrm{CO}_{2}}-c_{\mathrm{CO}_{2}} m_{\mathrm{CO}_{2}} \\
& =c_{\mathrm{COE}}+E_{\mathrm{CO}_{2}} T_{\mathrm{CO}_{2}} /\left(W_{\text {net }} H\right)-M_{\mathrm{CO}_{2}} c_{\mathrm{CO}_{2}} /\left(W_{\text {net }} H\right) \text {, } \\
& c_{\mathrm{CAC}}^{\prime \prime \prime}=c_{\mathrm{CAC}}+\left(\frac{E_{\mathrm{CO}_{2}, 1} T_{\mathrm{CO}_{2}}-M_{\mathrm{CO}_{2}, 1} c_{\mathrm{CO}_{2}}}{W_{\mathrm{net}, 1} H}-\frac{E_{\mathrm{CO}_{2}, 0} T_{\mathrm{CO}_{2}}}{W_{\mathrm{net}, 0} H}\right) / \\
& \left(\frac{E_{\mathrm{CO}_{2}, 0}}{W_{\text {net }, 0} H}-\frac{E_{\mathrm{CO}_{2}, 1}}{W_{\text {net }, 1} H}\right) \\
& =c_{\mathrm{CAC}}+\left[\frac{\left(1-\eta_{\mathrm{C}, 1}\right) \eta_{\mathrm{e}} E_{\mathrm{CO}_{2}, 0} T_{\mathrm{CO}_{2}}-\eta_{\mathrm{C}, 1} \eta_{\mathrm{e}} E_{\mathrm{CO}_{2}, 0} c_{\mathrm{CO}_{2}}}{W_{\text {net, } 1}}\right. \\
& \left.-\frac{E_{\mathrm{CO}_{2}, 0} T_{\mathrm{CO}_{2}}}{W_{\text {net }, 0}}\right] /\left[\frac{E_{\mathrm{CO}_{2}, 0}}{W_{\text {net }, 0}}-\frac{\left(1-\eta_{\mathrm{C}, 1}\right) \eta_{\mathrm{e}} E_{\mathrm{CO}_{2}, 0}}{W_{\text {net }, 1}}\right] \\
& =c_{\mathrm{CAC}}-T_{\mathrm{CO}_{2}}-c_{\mathrm{CO}_{2}} / \beta \text {, } \\
& c_{\mathrm{CCC}}^{\prime \prime \prime}=c_{\mathrm{CCC}}+\left(\frac{E_{\mathrm{CO}_{2}, 1} T_{\mathrm{CO}_{2}}-M_{\mathrm{CO}_{2}, 1} c_{\mathrm{CO}_{2}}}{W_{\text {net, } 1} H}-\frac{E_{\mathrm{CO}_{2}, 0} T_{\mathrm{CO}_{2}}}{W_{\text {net }, 0} H}\right) / \\
& \left(\frac{M_{\mathrm{CO}_{2}, 1}}{W_{\text {net, } 1} H}\right) \\
& =c_{\mathrm{CCC}}+\left[\frac{\left(1-\eta_{\mathrm{C}, 1}\right) \eta_{\mathrm{e}} E_{\mathrm{CO}_{2}, 0} T_{\mathrm{CO}_{2}}-\eta_{\mathrm{C}, 1} \eta_{\mathrm{e}} E_{\mathrm{CO}_{2}, 0} c_{\mathrm{CO}_{2}}}{W_{\text {net, } 1}}\right. \\
& \left.-\frac{E_{\mathrm{CO}_{2}, 0} T_{\mathrm{CO}_{2}}}{W_{\text {net }, 0}}\right] /\left[\frac{\eta_{\mathrm{C}, 1} \eta_{\mathrm{e}} E_{\mathrm{CO}_{2}, 0}}{W_{\text {net }, 1}}\right] \\
& =c_{\mathrm{CCC}}-c_{\mathrm{CO}_{2}}-T_{\mathrm{CO}_{2}} \beta \text {, }
\end{aligned}
$$

in which the critical coefficient $\beta=W_{\text {net, } 1} /\left(W_{\text {net, } 0} \eta_{\mathrm{C}, 1} \eta_{\mathrm{e}}\right)-$ $\left(1-\eta_{\mathrm{C}, 1}\right) / \eta_{\mathrm{C}, 1}$, is actually the ratio of the critical $c_{\mathrm{CO}_{2}}$ to the critical $T_{\mathrm{CO}_{2}}$. Usually, $\beta<1$.

The critical lines where the $c_{\mathrm{COE}}$ of oxy-combustion plants equal those of conventional plants for three different loads are shown in Figure 6. Points on a line correspond to critical $c_{\mathrm{CO}_{2}}$ and critical $T_{\mathrm{CO}_{2}}$ values for a particular case. Above the line, the economic characteristics of oxy-combustion plants are better, whereas below the line, the economic characteristics of conventional plants are better. For example, for the critical line of the $2 \times 300 \mathrm{MW}$ subcritical

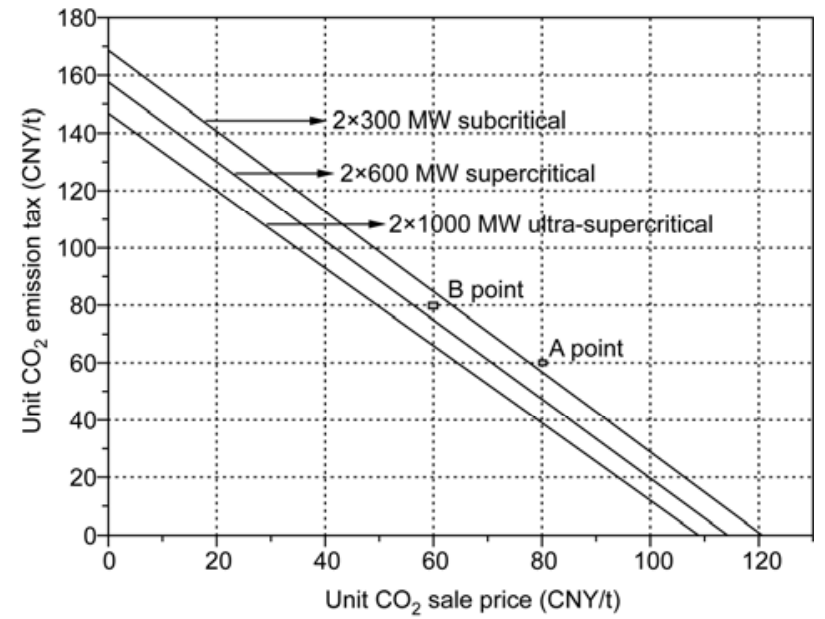

Figure 6 Relations between $T_{\mathrm{CO}_{2}}$ and $c_{\mathrm{CO}_{2}}$ when $c_{\mathrm{COE}, 0}$ equals $c_{\mathrm{COE}, 1}$.

case, the point $\mathrm{A}$ is above the line and it corresponds to $60 ¥ / \mathrm{t} T_{\mathrm{CO}_{2}}$ and $80 ¥ / \mathrm{t} c_{\mathrm{CO}_{2}}$. In this case, the $c_{\mathrm{COE}}$ of the oxycombustion plant is smaller and its economic characteristic is better; on the other hand, the point $\mathrm{B}$ is below the line and it corresponds to $80 ¥ / \mathrm{t} T_{\mathrm{CO}_{2}}$ and $60 ¥ / \mathrm{t} c_{\mathrm{CO}_{2}}$. In this case, the $c_{\mathrm{COE}}$ of the oxy-combustion plant is greater and its economic characteristic is worse. This result also reveals the difference between the $c_{\mathrm{CO}_{2}}$ and $T_{\mathrm{CO}_{2}}$.

\section{Sensitivity analysis}

\subsection{Effects of parameters}

A sensitivity analysis of some important parameters in the oxy-combustion plant, such as coal price, ASU cost, ASU power consumption and $\mathrm{CO}_{2}$ capture efficiency, was performed under the $2 \times 300 \mathrm{MW}$ subcritical plant model, and the results are shown in Figure 7 . This shows that $c_{\mathrm{COE}}$ is most correlated with $c_{\mathrm{F}}$, and that is because fuel costs contribute $62 \%-65 \%$ of $c_{\mathrm{COE}}$ of oxy-combustion plants. The following parameters are $\alpha$ and $W_{\mathrm{ASU}}$, because the net power outputs of oxy-combustion plants decrease significantly because of the ASUs (power consumptions are 16\%-18.5\% of total loads), and the $\alpha$ directly relates to the oxygen demand and the ASU power consumption. The influences of ASU cost, CPU power consumption, interest rate, loan percentage on the $c_{\mathrm{COE}}$ are also obvious, but the influence of CPU cost on the $c_{\mathrm{COE}}$ is slight, because its cost amounts to only about $2 \%$ of the static investment cost of the oxycombustion plants. For $c_{\mathrm{CAC}}$ and $c_{\mathrm{CCC}}$, the nine parameters considered have similar influences on them; and $r_{\mathrm{CO} 2}$ influences them most because it directly affects unit $\mathrm{CO}_{2}$ capture amounts and unit $\mathrm{CO}_{2}$ emission amounts in oxy-combustion plants. The other important parameters are $\alpha$ and $W_{\mathrm{ASU}}$. The influences of coal price, ASU cost, CPU power consumption, interest rate, loan percentage on them are also obvious. Similarly, the influences of CPU cost on them are slight. In 

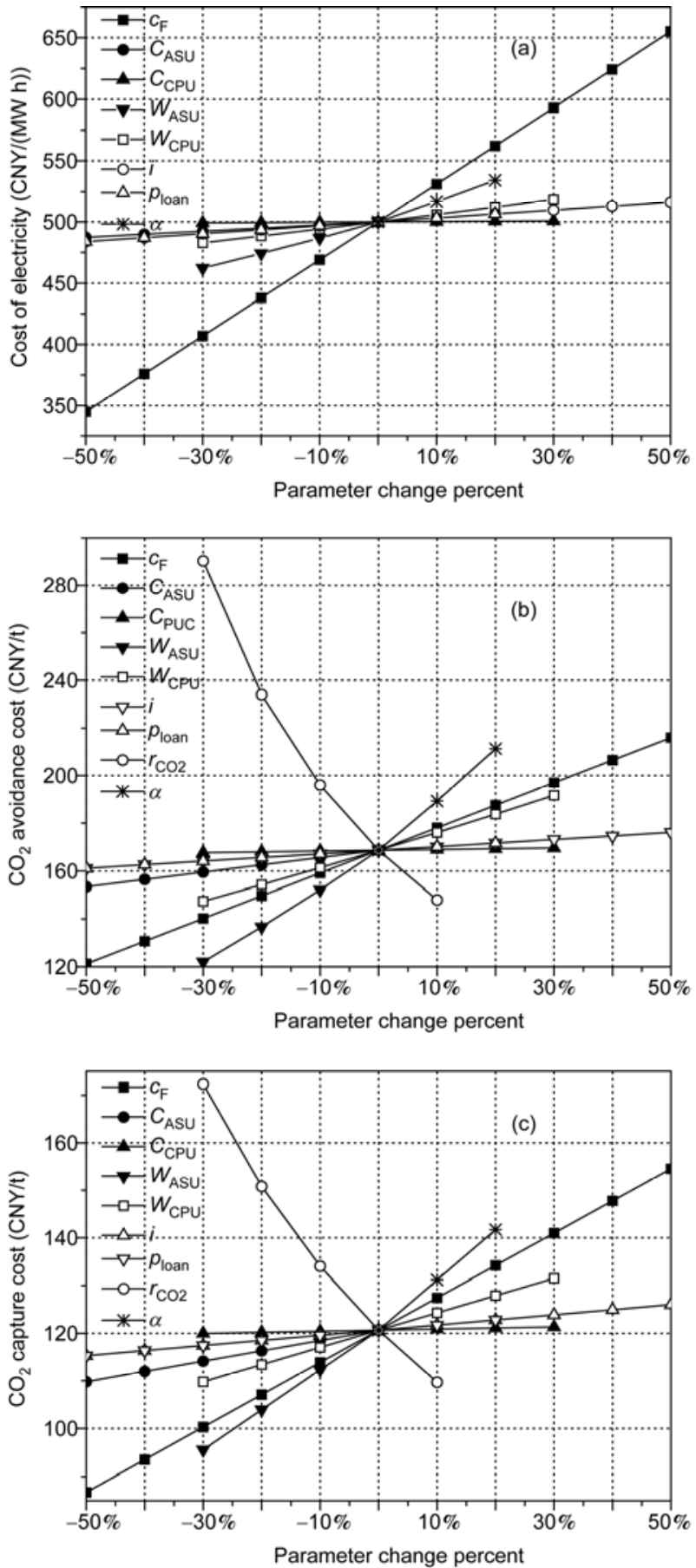

Figure 7 Results of the sensitivity analysis. (a) Influences of parameters on $c_{\mathrm{COE}}$; (b) influences of parameters on $c_{\mathrm{CAC}}$; (c) influences of parameters on $c_{\mathrm{CCC}}$.

general, the influences of the parameters on these three costs are similar. The results show that the influences of $\alpha$ and $W_{\mathrm{ASU}}$ on the $c_{\mathrm{COE}}$ of the oxy-combustion plant are less than that of the coal price. But the influences of $\alpha$ and $W_{\mathrm{ASU}}$ on the $c_{\mathrm{CAC}}$ and $c_{\mathrm{CCC}}$ are greater than that of the coal price because ASU consumes much power and the influences of coal price on $c_{\mathrm{COE}}$ of conventional plants and oxy-combus- tion plants are similar. In addition, the influences of $\mathrm{SO}_{x}$ and $\mathrm{NO}_{x}$ emission taxes, $\mathrm{S}$ and $\mathrm{N}$ contents of coal on the three costs were also analyzed in the paper. The results show that the influences are slight, so they are not shown in Figure 7.

\subsection{Effects of coal samples}

To analyse the influence of different coal samples on the economic characteristics of the oxy- combustion technology, three different coal samples were further chosen to conduct a similar calculation process. The ultimate analysis results and lower heating values of these coal samples are all listed in Table 4.

Considering the $2 \times 300 \mathrm{MW}$ subcritical plant for example, the $c_{\mathrm{COE}}, c_{\mathrm{CAC}}$ and $c_{\mathrm{CCC}}$ results corresponding to the four coal samples are listed in Table 5. The results show that the influence of different coal samples on the economic characteristics of the oxy-combustion technology is not obvious, and the results obtained in this paper are universally significant.

\section{Conclusion}

In this paper, a techno-economic evaluation of $2 \times 300 \mathrm{MW}$ subcritical, $2 \times 600 \mathrm{MW}$ supercritical and $2 \times 1000 \mathrm{MW}$ ultra-supercritical oxy-combustion coal-fired power plants was performed. The results indicate that the electricity cost of a $2 \times 300 \mathrm{MW}$ oxy-combustion plant (with LIFAC desulphurization device) is $500.04 ¥ /(\mathrm{MW} \mathrm{h})$ (449.09 $¥ /(\mathrm{MW} \mathrm{h})$, $395.93 ¥ /(\mathrm{MW} \mathrm{h})$, are the equivalent values for the $2 \times 600$ MW and $2 \times 1000$ MW plants), which is 1.39 (similarly 1.38 , 1.36) times that of the corresponding conventional plant (equipped with the limestone-gypsum desulfurization system and SCR denitration system); its static investment cost is $1.19(1.23,1.25)$ times that of the corresponding conventional plant; its net power output is $0.73(0.74,0.75)$ times that of the corresponding conventional plant. The increase in the static investment cost is mainly because of the high commercial price of ASU, and the significant decrease of the net power output is mainly because of the high power consumption of the ASU and CPU systems. However, without considering the power consumption of the ASU and the CPU, the annualized costs of oxy-combustion plants increase slightly in comparison to conventional plants. This is because the desulfurization and denitration devices with

Table 4 Ultimate analysis results and lower heating values of three other coal samples

\begin{tabular}{llccccccc}
\hline Coal sample & $\begin{array}{c}\mathrm{M}_{\mathrm{ar}} \\
(\%)\end{array}$ & $\begin{array}{c}\mathrm{A}_{\mathrm{ar}} \\
(\%)\end{array}$ & $\begin{array}{c}\mathrm{C}_{\mathrm{ar}} \\
(\%)\end{array}$ & $\begin{array}{c}\mathrm{H}_{\mathrm{ar}} \\
(\%)\end{array}$ & $\begin{array}{c}\mathrm{O}_{\mathrm{ar}} \\
(\%)\end{array}$ & $\begin{array}{c}\mathrm{N}_{\mathrm{ar}} \\
(\%)\end{array}$ & $\begin{array}{c}\mathrm{S}_{\mathrm{ar}} \\
(\%)\end{array}$ & $\begin{array}{c}H_{\mathrm{i}} \\
(\mathrm{kJ} / \mathrm{kg})\end{array}$ \\
\hline Huangshi & 6 & 26.18 & 59.21 & 2.56 & 2.12 & 0.82 & 3.11 & 22310 \\
Datong & 9.1 & 21.94 & 55.78 & 3.34 & 8.11 & 1.14 & 0.59 & 21326 \\
Huangling & 7.27 & 26.48 & 53.06 & 2.88 & 8.79 & 0.81 & 0.71 & 20890 \\
\hline
\end{tabular}


Table $5 c_{\mathrm{COE}}, c_{\mathrm{CAC}}$ and $c_{\mathrm{CCC}}$ results corresponding to the four coal samples

\begin{tabular}{|c|c|c|c|c|}
\hline \multirow{2}{*}{ Coal sample } & \multicolumn{2}{|c|}{$c_{\mathrm{COE}}\left(¥(\mathrm{MW} \mathrm{h})^{-1}\right)$} & \multirow{2}{*}{$c_{\mathrm{CAC}}(¥ / \mathrm{t})$} & \multirow{2}{*}{$c_{\mathrm{CCC}}(¥ / \mathrm{t})$} \\
\hline & Conventional (FGD, SCR) & Oxy-combustion (LIFAC) & & \\
\hline Shenhua & 358.72 & 500.04 & 168.61 & 120.65 \\
\hline Huangshi & 360.07 & 504.84 & 173.04 & 123.34 \\
\hline Datong & 359.01 & 499.15 & 169.83 & 121.84 \\
\hline Huangling & 358.95 & 491.39 & 164.94 & 120.15 \\
\hline
\end{tabular}

high O\&M costs are avoided and the coal consumption amount may be reduced.

If the $\mathrm{CO}_{2}$ tax and $\mathrm{CO}_{2}$ sale price are considered, the economic property of the oxy-combustion technology could be competitive with the conventional combustion technology. For the oxy-combustion plants, the $\mathrm{CO}_{2}$ avoidance cost (viz. critical unit $\mathrm{CO}_{2}$ emission tax) is $168.61 ¥ / \mathrm{t}(157.64 ¥ / \mathrm{t}$, $146.89 ¥ / \mathrm{t}$ ), and the $\mathrm{CO}_{2}$ capture cost (viz. critical $\mathrm{CO}_{2}$ sale price) is $120.65 ¥ / \mathrm{t}(114.26 ¥ / \mathrm{t}, 108.90 ¥ / \mathrm{t})$.

The comparison of economic performance of the three plants with different loads shows that from the subcritical system to the supercritical system and finally the ultra-supercritical system, the economic characteristics increase significantly because of the decrease in the unit investment cost and the increase in the systems thermal efficiency. Sensitivity analysis shows that coal price, air excess factor, ASU power consumption and $\mathrm{CO}_{2}$ capture efficiency are the four parameters that most influence the economic performance of the oxy-combustion technology. The influence of the coal sample on the economic performance of the oxycombustion technology is not obvious.

\section{Nomenclature}

\section{Abbreviations}

ASU

Air separation unit

CAC

$\mathrm{CO}_{2}$ avoidance cost

$\mathrm{CCC}$

$\mathrm{CO}_{2}$ capture cost

$\mathrm{COE}$

Cost of electricity

CPU Flue gas clean and purification unit

FGD Wet flue gas desulfurization

IT Total investment cost

OM Operation and maintenance cost

SCR Selective catalytic reduction

\section{Scalars}

$C, c \quad$ Cost and unit cost

$E, e \quad$ Emission and unit emission amount

$H \quad$ Annual operation hours

$H_{\mathrm{i}} \quad$ Lower heating value of raw coal
$H_{\mathrm{n}} \quad$ Lower heating value of standard coal

$i \quad$ Interest rate

$M, m \quad$ Mass flowrate and unit mass flowrate

$N \quad$ Personnel numbers

$P \quad$ Loan period

$p \quad$ O\&M coefficient

$P_{\text {caco3 }} \quad$ Purity of limestone

$P_{\mathrm{CaSO} 4} \quad$ Purity of gypsum

$p_{\text {fa }} \quad$ Fixed assets formation percentage

$p_{\text {ia }} \quad$ Intangible and deferred assets percentage

$p_{\text {loan } \quad \text { Loan percentage }}$

$p_{\mathrm{lv}} \quad$ Residual value percentage

$p_{\mathrm{m}} \quad$ Material cost ratio

$p_{\mathrm{O}} \quad$ Other costs ratio

$r_{\text {ca2s }} \quad$ Mole ratio of $\mathrm{Ca}$ to $\mathrm{S}$

$r_{\mathrm{CO} 2} \quad \mathrm{CO}_{2}$ capture efficiency

$r_{\mathrm{pe}} \quad$ Auxiliary power ratio

$r_{\mathrm{W}} \quad$ Welfare and labor insurance coefficient

$T \quad$ Pollutant emission tax

$t_{\mathrm{C}} \quad$ Ratio of $\mathrm{C}_{\mathrm{ar}}$ transformed to be $\mathrm{CO}_{2}$

$t_{\mathrm{S}} \quad$ Ratio of $\mathrm{S}_{\mathrm{ar}}$ transformed to be $\mathrm{SO}_{2}$

$V, v \quad$ Volume and unit volume

$W \quad$ Power

$Y_{\mathrm{d}} \quad$ Depreciation period

\section{Greek letters}

$\begin{array}{ll}\alpha & \text { Air excess factor } \\ \beta & \text { Critical coefficient } \\ \eta & \text { Efficiency } \\ \xi & \text { Average interest rate }\end{array}$

\section{Subscripts}

$0 \quad$ Base (conventional) plant

1 Oxy-combustion plant

ar As-received basis

b Boiler

ef Effluent 


$\begin{array}{ll}\mathrm{F} & \text { Fuel } \\ \mathrm{N} & \mathrm{NO}_{x} \\ \text { net } & \text { Net power output } \\ \mathrm{O} & \text { Oxygen } \\ \text { pay } & \text { Payment } \\ \text { pw } & \text { Process water } \\ \mathrm{S} & \mathrm{SO}_{x}\end{array}$

This work was supported by the National Basic Research Program of China (2011CB707300), National Natural Science Foundation of China (50936001 and 50721005) and New Century Excellent Talents in University of China (NECT-10-0395).

1 Wang S. The global warming debate. Chinese Sci Bull, 2010, 55: 1961-1962

2 Zheng Y, Li H, Wu R, et al. Impact of technology advances on China's $\mathrm{CO}_{2}$ emission reduction. Chinese Sci Bull, 2010, 55: 1983-1992

3 Okawa M, Kimura N, Kiga T, et al. Trial design for a $\mathrm{CO}_{2}$ recovery power plant by burning pulverized coal in $\mathrm{O}_{2} / \mathrm{CO}_{2}$. Energ Convers Manage, 1997, 38(suppl): 123-127

4 Anderssen K, Johnsson F, Stromberg L. Large scale $\mathrm{CO}_{2}$ capture applying the concept of $\mathrm{O}_{2} / \mathrm{CO}_{2}$ combustion to commercial process data. VGB Powertech, 2003, 83: 29-33

5 Marion J, Nsakala N, Bozzuto C, et al. Engineering feasibility of $\mathrm{CO}_{2}$ capture on an existing US colafired power plant. In: Proceedings of the 26th International Conference on Coal Utilization and Fuel Systems. Clearwater, FL, USA: 2001. 941-952

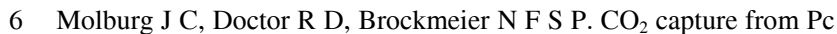
boilers with $\mathrm{O}_{2}$-firing. In: Eighteenth annual international Pittsburgh coal conference. Newcastle, NSW, Australia: 2001
7 Singh D, Croiset E, Douglas P L, et al. Techno-economic study of $\mathrm{CO}_{2}$ capture from an existing coal-fired power plant: MEA scrubbing vs. $\mathrm{O}_{2} / \mathrm{CO}_{2}$ recycle combustion. Energ Convers Manage, 2003, 44: 3073-3091

8 Kanniche M, Gros-Bonnivard R, Jaud P, et al. Pre-combustion, postcombustion and oxy-combustion in thermal power plant for $\mathrm{CO}_{2}$ capture. Appl Therm Eng, 2010, 30: 53-62

9 Xiong J, Zhao $\mathrm{H}$, Liu Z, et al. Techno-economic evaluation of $\mathrm{O}_{2}$ / $\mathrm{CO}_{2}$ recycle combustion system and mea scrubbing system based on thermoeconomics. J Engineer Thermophy, 2008, 29: 1625-1629

10 Xiong J, Zhao $\mathrm{H}$, Zheng $\mathrm{C}$, et al. An economic feasibility study of $\mathrm{O}_{2} / \mathrm{CO}_{2}$ recycle combustion technology based on existing coal-fired power plants in China. Fuel, 2009, 88: 1135-1142

11 Electric Power Planning and design Institute for China Power Engineering Consulting Group Corporation. Reference cost indexes in quota design for coal-fired projects (2009 levels) (in Chinese). Beijing: China Electric Power Press, 2010

12 Simbeck D R. $\mathrm{CO}_{2}$ mitigation economics for existing coal-fired power plants. In: First national conference on carbon sequestration. Washington DC: 2001

13 Andersson K, Johnsson F. Process evaluation of an 865 MWe lignite fired $\mathrm{O}_{2} / \mathrm{CO}_{2}$ power plant. Energ Convers Manage, 2006, 47: 3487-3498

14 Sun K, Zhong Q. Design, Construction and Operation of Flue Gas Desulfurization Systems in Coal-Fired Power Plants. Beijing: Chemistry Industry Press, 2005

15 Sun K, Zhong Q. Flue gas denitration technology and engineering applications in coal-fired power plants (in Chinese). Beijing: Chemistry Industry Press, 2007

16 Liu X. SCR DeNO $x$ technologies applied in the 300 MW units of Hengyun Power Plant. Electric Power, 2006, 39: 86-89

17 Huang M. Environmental and economic analysis of FGD projects in Jiangsu province. Electric Power Environ Protect, 2006, 22: 54-57

18 Liu D, Yang Y, Yang K, et al. Research on the production cost of coal-fired power generating unit with consideration of environmental costs. Electric Power, 2005, 38: 24-28

Open Access This article is distributed under the terms of the Creative Commons Attribution License which permits any use, distribution, and reproduction in any medium, provided the original author(s) and source are credited. 